\title{
Potential Soil Erosion of Selected Habitat Types in the High Desert Region of Central Oregon
}

\author{
JOHN C. BUCKHOUSE AND JEFFREY L. MATTISON
}

\begin{abstract}
During the summers of 1975 and 1976 , an infiltration/sedimentation study was conducted in the Bear Creek watershed of central Oregon. A Rocky Mountain infiltrometer was used to simulate high intensity rainfall over $\mathbf{4 6 8}$ sediment plots. The Bear Creek watershed was divided into seven ecological land units which were further refined into ten tentative habitat types based upon an associated table developed from vegetation and soils field data. Tractor logging in the mixed forest caused a significant increase in soil loss. In nonforested units, a high natural variability in sediment production within sites tended to mask any differences that may have resulted from a management treatment. Significant differences that did occur appeared to be closely related to differences in soils and ecological condition. Beyond the identification of specific sediment production potentials, this work investigated the value of the habitat type level of ecological refinement in relation to hydrologic response.
\end{abstract}

Management of semiarid range watersheds is based primarily upon the harvest of natural resources and the realization of nontangible benefits from the land and its vegetation. Watershed concerns on these rangelands deal with soil stability and protection and the quantity and quality of water that is produced. Management, therefore, requires the maintenance of a vegetation and soil cover that is able to utilize and store precipitation at its maximum effectiveness.

The purpose of this study was to investigate ecological land units within the Bear Creek watershed, $65 \mathrm{~km}$ east of Bend, Oregon, in terms of their susceptibility to surface erosion.

\section{Study Area and Methods}

The Bear Creek drainage covers approximately 53,000 ha with elevations ranging from $988 \mathrm{~m}$ at Prineville Reservoir to $1,909 \mathrm{~m}$ at Drake Butte in the Ochoco National Forest. Bear Creek is a tributary of the Upper Crooked River drainage with runoff storage in Prineville Reservoir. The sediment production values calculated from those ecological units indicate only potential erodability which could ultimately contribute to the degradation of water quality.

The authors are assistant professor, Rangeland Resources Program, Oregon State University, Corvallis, Oregon, and wildlife biologist. Bureau of Land Management. Redding, California, respectively.

The work upon which this report is based was supported by funds provided by the U.S. Department of the Interior, Office of Water Resources and Research, as authorized by the Water Resources Research Act of 1964. The authors wish to acknowledge Darwin Jeppesen, soil scientist, Bureau of Land Management; Thomas Bunch, county extension agent, Oregon State Univcrsity; and William McCormack, Crook County rancher for the valuable assistance they rendered throughout all phases of the study. This study is submitted as Technical Paper No. 5043, Oregon Agricultural Experiment Station.

Manuscript received December 19, 1979.
A Mixed Forest unit covered approximately $17 \%$ of the watershed in the Ochoco National Forest. Western juniper (Juniperus occidentalis) woodlands were the most common vegetation type, and covered approximately $70 \%$ of the watershed. Shrublands, composed primarily of big sagebrush (Artemisia tridentata) and rabbitbrush (Chrysothamnus spp.) covered the remaining $13 \%$ of the watershed.

The study areas were represented by four soil orders and three undifferentiated soil types. Mollisols have developed from the Clarno and John Day formations and are high in sedimentary clays. This order covered approximately $80 \%$ of the watershed and was primarily associated with the mixed forest and juniper woodland vegetation types. Soils of the Aridisol order were younger, loamy or sandy in texture, and developed from basalt, volcanic ash, and pumice. These soils were associated with the shrubland vegetation found on the High Lava Plains, alluvial fans, and stream terraces adjacent to Bear Creek. The Day clay, a Vertisol, was characterized by a high shrink/swell capacity that created extensive deep surface cracking during the droughty summer months, and occurred as small inclusions throughout the watershed. Such soils can be very productive, and generally supported big sagebrush/bunchgrass communities. An unnamed Entisol also was found as scattered inclusions at lower elevations in the watershed and may be associated with recent exposures of old sedimentary formations. These soils are extremely fluffy and have calcium carbonates in the surface horizon. Understory is sparse on these sites.

Ecological land units and eventually habitat types were identified using a combination of aerial photography, vegetation and soil maps, and groundtruth techniques patterned after Daubenmire's (1968) habitat type classification.

Field sampling to provide the vegetative data base was conducted using the macroplot method developed by Poulton and Tisdale (1961) during 1975 and 1976. The macroplot, which measured $15 \mathrm{~m}$ by $30 \mathrm{~m}$, was oriented with four $30-\mathrm{m}$ transects parallelling the contour. Canopy coverage was determined by the line intercept method on these transects. Distribution and occurence of vegetation was sampled with a nested plot technique (Mueller-Dombois and Ellenberg 1974) in which frequency was recorded. A belt transect $1 \mathrm{~m}$ by $30 \mathrm{~m}$, was used to sample shrub density. Shrub species were tallied by height classes $(0-15 \mathrm{~cm}$ and $>30 \mathrm{~cm}$ ) for living plants. Additionally, trees greater than $1 \mathrm{~m}$ in height were measured using crown diameters for western juniper and with a forest densiometer for ponderosa pine (Pinus ponderosa). Herbaceous cover, relative amounts of litter, pavement, and bare ground were measured within each sediment plot using the ocular estimate method. A point frequency method, with 100 points/plot in every tenth plot, was used in conjunction with the ocular estimate method to serve as a means of checking the estimates.

Soils at each macroplot were classified to most similar series or association in all cases and to individual series where possible (U.S.D.A. 1975). 
A Rocky Mountain Infiltrometer (Dortignac 1951) was used during the summer months of 1975 and 1976 to determine the soil loss for each vegetation-soil unit. The pump and sprinkler were set to approximate a 28 -minute storm producing about $10 \mathrm{~cm}$ of precipitation per hour. This storm was chosen since it mimics the high intensity/low frequency convectional storms which occur in this region during the summer.

The erosion trials consisted of randomly locating six replications of three plot frames (each $30 \mathrm{~cm} \times 75$ ) along the contour immediately above and below the vegetation macroplot for the nonforest vegetation-soil units, and three replications immediately below the macroplot for the forest units. Runoff water and suspended sediments were subsequently collected and the data used in the calculation of soil loss, infiltration, and runoff values. Additionally, a hydrologic potential which is the ratio of runoff to rainfall, was calculated for each site (Hewlitt and Nutter 1969). This potential is indicative of the relative response to a precipitation event.

Vegetation data was organized into a species associated table and used to determine ecological land units and habitat types. Hydrologic data were analyzed through a modified randomized block design to quantify the variation between and within habitat types of a particular ecological land unit. One-factor analysis of variance was used to analyze differences within habitat types and two-factor analysis of variance was used to compare habitat types within an ecological land unit.

\section{Results and Discussion}

The Bear Creek watershed was divided into seven ecological land units, tentatively containing ten habitat types following on-the-ground analysis. These ecological land units were grouped into two general categories (forest and non-forest) for statistical analysis.

\section{Forest}

\section{Mixed Forest Unit}

The Mixed Forest unit was tentatively classified into two habitat types (h.t.): Pseudotsuga menziesii/Calamagrostis rubescens h.t. (Daubenmire 1952) (Psme/Caru) and Pinus ponderosa/Festuca idahoensis h.t. (Daubenmie and Daubenmire 1968 (Pipo/Feid).

The Psme/Caru h.t. had been managed for ponderosa pine. Elk sedge (Carex geyeri), heartleaf arnica (Arnica cordifolia), and western hawkweed (Hieracium albertinum) occurred as important subdominants in the understory. The soil was a well-drained, frigid Ultic Paleoxeroll. Sediment production ranged from zero to $73 \mathrm{~kg} /$ ha with a mean of 47 $\mathrm{kg} / \mathrm{ha}$ and a hydrologic potential of 30 .

The Pipo/Feid h.t. was dominated by ponderosa pine with elk sedge and heartleaf arnica occurring in subdominant roles. Sediment production varied from 28 $\mathrm{kg} /$ ha to $1,860 \mathrm{~kg} / \mathrm{ha}$ with a mean of $331 \mathrm{~kg} / \mathrm{ha}$ and a hydrologic potential of 43 .

Analysis of variance comparing the two habitat types showed no significant differences in sediment production. When two similar Psme/Caru sites which had been tractor logged were examined, we found that the sediment produced from the first site ranged from $218 \mathrm{~kg}$ / ha to 2,995 $\mathrm{kg} / \mathrm{ha}$ with a mean of $1,365 \mathrm{~kg} / \mathrm{ha}$, while the second site varied from $85 \mathrm{~kg} /$ ha to $19,900 \mathrm{~kg} / \mathrm{ha}$ with a mean of 7,013 $\mathrm{kg} / \mathrm{ha}$. Analysis of variance showed no significant differences between the logged sites. However, when compared to the untreated sites, significantly more sediment was produced $(\mathrm{P} \leq .05)$. The increase in soil loss resulting from this tractor logging operation was highly variable within both disturbed sites. This suggested a differing
Table 1. Mean sediment potentials for selected ecological land units and habitat types within the Bear Creek watershed.

\begin{tabular}{|c|c|c|}
\hline Habitat type & $\begin{array}{l}\text { Sediment } \\
\text { production } \\
(\mathrm{kg} / \mathrm{ha})\end{array}$ & $\begin{array}{l}\text { Hydrologic } \\
\text { potential } \\
(\%)\end{array}$ \\
\hline Mixed forest & 189 & \\
\hline Psuedotsuga menziesii/Calamagrostis & 47 & 30 \\
\hline Pinus ponderosa/Festuca idahoensis h.t. & 331 & 43 \\
\hline $\begin{array}{l}\text { Low sagebrush } \\
\quad \text { Artemisia arbuscula/Festuca idahoensis- }\end{array}$ & 740 & \\
\hline Agropyron spicatum h.t. & 740 & 33 \\
\hline Sandy shrubland & 785 & \\
\hline $\begin{array}{l}\text { Artemisia tridentata/Stipa comata h.t. } \\
\text { Adobeland }\end{array}$ & $\begin{array}{l}785 \\
785\end{array}$ & 30 \\
\hline Agropyron spicatum-Poa sandbergii h.t. & 785 & 34 \\
\hline Big sagebrush & 1437 & \\
\hline $\begin{array}{l}\text { Artemisia tridentata/Festuca idahoensis- } \\
\text { Agropyron spicatum h.t. w/o Juniperus } \\
\text { occidentalis } \\
\text { Artemisia tridentata/Festuca idahoensis- }\end{array}$ & 914 & 24 \\
\hline $\begin{array}{l}\text { Agropyron spicatum h.t. w/invading } \\
\text { Juniperus occidentalis } \\
\text { Juniper woodland }\end{array}$ & $\begin{array}{l}1961 \\
1636\end{array}$ & 41 \\
\hline $\begin{array}{l}\text { Juniperus occidentalis/Artemisia tridentata/ } \\
\text { Festuca idahoensis-Agropvron spicatum h.t. } \\
\text { Juniperus occidentalis/Artemisia tridentata/ }\end{array}$ & 2912 & 52 \\
\hline $\begin{array}{l}\text { Festuca idahoensis-Agropyron spicatum h.t. } \\
\text { Stipa thurberiana phase } \\
\text { Juniperus occidentalis/Stipa thurberiana h.t. }\end{array}$ & $\begin{array}{r}411 \\
1538\end{array}$ & $\begin{array}{l}18 \\
41\end{array}$ \\
\hline Mixed steppe & 2300 & \\
\hline $\begin{array}{l}\text { Juniperus occidentalis / Artemisia tridentata } \\
\text { ssp. vaseyana/Festuca idahoensis h.t. } \\
\text { Artemisia tridentata ssp. vaseyana / Festuca }\end{array}$ & 4124 & 53 \\
\hline idahoensis h.t. & 477 & 21 \\
\hline
\end{tabular}

magnitude in the severity of the impact within these sites. Compaction is often associated with such logging practices and may explain some of the variation measured within the sites. Highly skewed values were recorded for one of the sites which contained burned debris and suggested a potential repellency may exist at the soil surface following firc on these soils (Buckhouse 1975).

\section{Nonforest}

\section{Mixed Steppe Unit}

The Mixed Steppe unit was tentatively classified into two habitat types: Juniperus occidentalis/Artemisia tridentata spp. vaseyana/Festuca idahoensis h.t. (similar to Driscoll 1964) (Juoc/Artrv/Feid) and Artemisia tridentata ssp. vaseyana/Festuca idahoensis h.t. (Winward 1970) (Artr/Feid).

The Juoc/Artrv/Feid h.t. was characterized by two sites. Idaho fescue was the dominant grass, with bluebunch wheatgrass (Agropyron spicatum) and sedge (Carex spp.) as subdominants on site 1. Sandberg's bluegrass (Poa sandbergii) was the only grass species which was widely distributed on site 2, and the juniper at this site was primarily old growth, supporting the foliose lichen Letharia vulpinus and having flat crowns, which are indicators of old growth according to Burkhardt and Tisdale (1969). The forb component was dominated by low pussytoes (Antennaria dimorpha) and the moss Tortula ruralis. Both sites occurred on a deep, well-drained clay loam formed in old sediments of volcanic origin. The sediment produced from site 1 averaged $7,396 \mathrm{~kg} / \mathrm{ha}$ with a range of $1,179-26,500 \mathrm{~kg} / \mathrm{ha}$ and had a hydrologic potential of 56 . Site 2 varied from $198 \mathrm{~kg} /$ ha to $1,717 \mathrm{~kg} / \mathrm{ha}$ with a mean of $85 \mathrm{~kg} / \mathrm{ha}$ and a hydrologic 
potential of 50. Due to the high variability within both sites of this habitat type, there was no significant difference $(P<.05)$ in sediment between them.

The Artv/Feid h.t. was characterized by two sites. The first site had more mountain big sagebrush, more bottle brush squirreltail (Sitanion hystrix), and fewer forbs than the second site, which suggested past heavy grazing. The second site supported a high amount of Wyeth's buckwheat (Eriogonum heracleoides) and revealed no evidence of recent disturbance. The sediment produced at the first site averaged $660 \mathrm{~kg} /$ ha and varied from $215 \mathrm{~kg} / \mathrm{ha}$ to 1,469 $\mathrm{kg} /$ ha with a hydrologic potential of 27 . The second site had a hydrologic potential of 15 , and its sediment potentials ranged from 1 to $673 \mathrm{~kg} /$ ha with a mean of $295 \mathrm{~kg} / \mathrm{ha}$. Analysis of variance indicated that these sites did not differ significantly in sediment production $(P<.05)$.

\section{Juniper Woodland Unit}

The Juniper Woodland unit was tentatively represented by two habitat types: Juniperus occidentalis/Artemisia tridentate/Festuca idahoensis-Agropyron spicatum h.t. (similar to Driscoll 1964) (Juoc/Artr/Feid-Agsp) and Juniperus occidentalis/Stipa thurberiana h.t. (Youtie and Winward 1977) (Juoc/Stth).

The Juoc/Artr/Feid-Agsp h.t. was characterized on four sites. Two of the sites (sites 3 and 4) appeared to constitute the Stipa thurberiana phase described by Eckert (1957). Big sagebrush was dominant on all four sites; however, low sagebrush was often present within or adjacent to these sites. Green rabbitbrush (Chrysothamnus viscidiflorus) and granite gilia (Leptodactylon pungens) occurred on all four sites. On sites 1 and 2, Sandberg's bluegrass was the dominant herbaceous species. Site one had a hydrologic potential of 55 , with a mean sediment production of 3,739 $\mathrm{kg}$ / ha; and although soil loss varied from $701-6,144 \mathrm{~kg} / \mathrm{ha}$, it was consistently high. Site two had a hydrologic potential of 49 , and the mean sediment production was $2,715 \mathrm{~kg} / \mathrm{ha}$. The soil loss was more variable on this site, ranging from $436-5,888 \mathrm{~kg} / \mathrm{ha}$. Analysis of variance indicated that these two sites were not significantly different. Sites 3 and 4 , the Stipa phase of Juoc/Artr/Feid-Agsp h.t. was characterized by Thurber's needlegrass (Stipa thurberiana) dominating the herbaceous understory. Sandberg's bluegrass and Idaho fescue occurred as subdominants. Site 3 had an average soil loss of $177 \mathrm{~kg} / \mathrm{ha}$ with a range of $1-560 \mathrm{~kg} / \mathrm{ha}$ and a hydrologic potential of 15 . Site 4 produced an average sediment load of $645 \mathrm{~kg} / \mathrm{ha}$ and had more variation than the first site, losing from $55-1,459 \mathrm{~kg} /$ ha of soil. The hydrologic potential for this site was 21 . The Stipa phase, sites 3 and 4 exhibited significantly $(P \leq .01)$ less soil loss than did the other Juoc/Artr/Feid-Agsp sites.

The second habitat type, Juniperus occidentalis/Stipa thurheriana was represented by one site. Hood's phlox (phlox hoodii) dominated the forb component. The occurrence of Sandberg's bluegrass was less than that found on the other woodland sites. The soil was a Calcic Argixeroll, expressed as a gravelly loam with residual pavement. The hydrologic potential was 41 . The average soil loss for this site was $1,528 \mathrm{hg} /$ ha with a range of $525-2,585$ $\mathrm{kg} / \mathrm{ha}$.

\section{Big Sagebrush Unit}

This unit was tentatively represented by the Artemisia tridentata/Festuca idahoensis-Agropyron spicatum habitat type (similar to Hall 1973) (Artr/Feid-Agsp) and was characterized by four sites. The first site was located on a light loam soil which was classified as a Calcic Pachic Agrixeroll. Invading juniper was cut from this site in 1973 and the area had subsequently been protected from livestock grazing for 3 years. Sediment production at this site averaged $2,778 \mathrm{~kg} /$ ha and ranged from $107 \mathrm{~kg} / \mathrm{ha}$ to 7,574 $\mathrm{kg} / \mathrm{ha}$. The hydrologic potential of the site was 37 . The second site had juniper present and very little understory vegetation. With a juniper overstory, Idaho fescue would potentially become codominant since it is closely associated with the litter which accumulates around the base of the tree. The average soil loss for site 2 was $1,145 \mathrm{~kg} / \mathrm{ha}$, varying from $86-3,648 \mathrm{~kg} / \mathrm{ha}$. The hydrologic potential was 45 . Site 3 was located on the gently sloping toe of a steep north aspect. This site would probably favor bluebunch wheatgrass at climax, but was dominated by Sandberg's bluegrass, cheatgrass (Bromus tectorum) and needle-and-thread grass (Stipa comata). The soil was a deep loam with volcanic ash influence, classified as a Calcic Haploxeroll. The average sediment produced from the site was $1,510 \mathrm{~kg} / \mathrm{ha}$ and ranged from $701-3,533 \mathrm{~kg} / \mathrm{ha}$. Analysis of variance indicated that this site was not significantly different from the previously mentioned sites with juniper overstory. The fourth big sagebrush site was located on the High Lava Plains. Bottlebrush squirreltail is the most frequently occurring species, and green rabbitbrush is a codominant with big sagebrush. Thurber's needlegrass and Idaho fescue are currently subdominants. The soil was a sandy loam textured Xerollic Camborthid. The average sediment produced from this site was $318 \mathrm{~kg} / \mathrm{ha}$ and varied from $12-1,045 \mathrm{~kg} / \mathrm{ha}$. This site had a hydrologic potential of 19 .

\section{Sandy Shrubland Unit}

This unit was tentatively represented by the Artemisia tridentata/Stipa comata habitat type (Winward 1970) (Art/Stco) and was characterized on two sites. Juniper was present in and around the first site, but not the second. There were few forbs in this habitat type. The soil on both locations was Xerollic Camborthid. This silty clay loam was derived from alluvium that reflects a volcanic origin and was high in pumice and ash. The first site was dominated by green rabbitbrush ( $9 \%$ crown cover) with big sagebrush as a subdominant ( $5 \%$ crown cover). Needle-and-thread grass was the dominant herbaceous species with bottlebrush squirreltail, Sandberg's bluegrass and cheatgrass playing subdominant roles. The average sediment production at this site was $963 \mathrm{~kg} / \mathrm{ha}$ and varied from $55-1,823 \mathrm{~kg} / \mathrm{ha}$. The second site was a homogeneous grassland with needleandthread grass as the obvious dominant. Cheatgrass was the subdominant species. The shrub component was inconspicuous and, while big sagebrush was present within the macroplot, only a single green rabbitbrush was recorded. This site produced a mean sediment loss of 606 $\mathrm{kg} / \mathrm{ha}$ and varied from $237-1,518 \mathrm{~kg} / \mathrm{ha}$. The hydrologic potential for both sites was essentially the same, 30 and 31 respectively. Analysis of variance showed no significant erosional differences between these sites.

\section{Low Sagebrush Unit}

This unit was tentatively represented by the Artemisia arbuscula/ Festuca idahoensis-Agropyron spicatum habitat type (similar to Hall 1973) (Arar/Feid-Agsp) and was characterized on four sites. The first sites were closely associated with the Juniper Woodland Unit, as scabland inclusions within the woodland area. The third and fourth 
sites were located on the High Lava Plains and on the north slope of Bear Creek Butte, respectively. Low sagebrush (Artemisia arbuscula) dominated all sites, with green rabbitbrush as a subdominant. Western juniper was present as an invader. Sandberg's bluegrass was the most frequent species on three of the sites. Bottlebrush squirreltail was common on all sites. Hood's phlox, low pussytoes and cushion buckwheat (Eriogonum ovalifolium) have high (100\%) constancy for all sites. At site 1 , Idaho fescue was dominant, and junegrass (Koeleria cristata) occurred in a subdominant role. Juniper was invading downslope along the upper boundary of this site. The soil was a shallow Aridic Paleoxeroll. This site produced from 113-641 kg/ha of sediment with a mean of $340 \mathrm{~kg} / \mathrm{ha}$. The hydrologic potential was 21 . The second site occurred within a juniper woodland area. Sandberg's bluegrass and bottlebrush squirreltail were the most frequent grass species encountered. The soil was also an Aridic Paleoxeroll, clay loam in texture. This site produced the most sediment from this habitat type, with an average of $1,347 \mathrm{~kg} / \mathrm{ha}$ and a range of $200-1,883 \mathrm{~kg} / \mathrm{ha}$. The hydrologic potential of this site was 50 . On the third site, juniper occurred infrequently, and green rabbitbrush was the subdominant of the shrub layer. Idaho fescue was the dominant grass species, and Thurber's needlegrass occurred as the subdominant grass species. The soil was an Aridisol, a Xerollic Camborthid, with a sandy loam texture. The average soil loss from this site was 630 $\mathrm{kg} /$ ha varying from $40-1,230 \mathrm{~kg} / \mathrm{ha}$. The hydrologic potential for this location was 25 . The fourth site had low sagebrush more widely distributed than on any of the other sites. Green rabbitbrush was the subdominant shrub. Western juniper was present, but its distribution was scattered and it was uncommon within this type. Although Sandberg's bluegrass occurred with the greatest frequency, bluebunch wheatgrass was believed to be the potential herbaceous dominant. The soil for this site was a frigid Lithic Argixeroll. It had a loam texture and a gravelly residual surface horizon. The mean sediment loss was 642 $\mathrm{kg} / \mathrm{ha}$ and ranged from $399 \mathrm{~kg} / \mathrm{ha}$ to $727 \mathrm{~kg} / \mathrm{ha}$. The hydrologic potential was 27 for this location.

Analysis of variance indicated significantly $(P \leq .01)$ more soil loss from the poorer condition sites ( 2 and 4 ) than from the better condition sites ( 1 and 3 ).

\section{Adobeland Unit}

The Adobeland Unit was tentatively represented by the Agropyron spicatum-Poa sandbergii habitat type (Daubenmire 1970) (Agsp-Posa) and was characterized on one site.

This habitat type was found on a Vertisol that has a high shrink/swell capacity. Juniper was invading this location; $90 \%$ of the trees were young, probably less than 50 years old, with a crown less than $2 \mathrm{~m}$ in diameter. Big sagebrush was present within the site but accounted for only $2 \%$ of the ground cover. This site was dominated by bluebunch wheatgrass with Sandberg's bluegrass as the subdominant species. The forb component was very diverse, similar to the Mixed Steppe Unit, but with more arid species. Hood's phlox and low pussytoes were the natural dominants in this component, which make the site similar to the low sagebrush types which were found on shallow soils. The soil was a deep, dark red clay of the Typic Chromoxerert subgroup. The average sediment produced at this site was $785 \mathrm{~kg} /$ ha with soil losses varying from $265-2,039 \mathrm{~kg} / \mathrm{ha}$. The hydrologic potential was 34 .

\section{Conclusions}

The majority of the soils in the Bear Creek watershed are of the fine montmorillonitic soil family. These soils are derived from volcanic parent material and exhibit a considerable influence from ash and pumice. This family was consistently high in sediment production when total ground cover was low. Generally, soil loss from simulated high-intensity rainfall exceeded $1,000 \mathrm{~kg} / \mathrm{ha}$ on this soil family. On the other hand, the Aridisol soils, found on the High Lava Plains, are members of the coarse loamy mixed family, and sediment production rarely exceeded 1,000 $\mathrm{kg} / \mathrm{ha}$.

Mean sediment potentials produced on the ecological land units ranged from $189 \mathrm{~kg} / \mathrm{ha}$ in the Mixed Forest to $2,300 \mathrm{~kg} /$ ha on the Mixed Steppe Unit (Table 1). Potential for soil loss in relation to intense rainfall was highly variable among habitat types, with means ranging from 47 to 4,124 $\mathrm{kg} / \mathrm{ha}$. Our results indicate that with increasing ecological interpretation, including habitat type and range condition, more reliable index of soil erodability can be developed.

\section{Literature Cited}

Buckhouse, J.C. 1975. Water quality impact of burning and grazing on a chained pinyon-juniper site in southeastern Utah. Ph.D. thesis, Utah State Univ., Logan, Utah. 103 p.

Burkhardt, J.W., and E.W. Tisdale. 1969. Nature and successional status of western juniper vegetation in Idaho. J. Range Manage. 22: 264-270.

Daubenmire, R. 1952. Forest vegetation of northern Idaho and adjacent Washington and its bearing on concepts of vegetation classification. Ecological Monogr. 22: 301-330.

Daubenmire, R. 1968. Plant Communities: A Textbook of Plant Synecology. Harper and Row Publ., N.Y. 300 p.

Daubenmire, R. 1970. Steppe vegetation of Washington. Washington Agr. Exp. Sta. Bull. 62. 131 p.

Daubenmire, R., and J. Daubenmire. 1968. Forest vegetation of eastern Washington and northern Idaho. Washington Agr. Exp. Sta. Tech. Bull. $60.140 \mathrm{p}$.

Dortignac, E.J. 1951. Design and operation of the Rocky Mountain infiltrometer. U.S. Forest Serv., Rocky Mt. Forest and Range Exp. Sta. Pap. 5. Fort Collins, Colo. $68 \mathrm{p}$.

Driscoll R.S. 1964. Vegetation-soil units in the central Oregon juniper zone. U.S.D.A. Forest Serv. Res. Pap. PNW-19. 60 p.

Eckert, R.E. 1957. Vegetation-soil relationships in some Artemisia types in Harney and Lake Counties, Oregon. Ph.D. thesis, Oregon State College, Corvallis, Ore. 208 p.

Hall, F.C. 1973. Plant communities of the Blue Mountain in eastern and southeastern Washington. U.S. Dep. Agr. Forest Serv. PNW Reg. R6 Guide 3-1. 62 p.

Hewlett, John D. and Wade L. Nutter. 1969. An outline of forest hydrology. Univ. Georgia Press, Athens, Ga. 137 p.

Mueller-Dombois, D., and H. Ellenberg. 1974. Aims and methods of vegetation ecology. John Wiley and Sons, N.Y. 547 p.

Poulton, C.E., and E.W. Tisdale. 1961. A quantitative method for the description and classification of range vegetation. J. Range Manage. 14: 30-21.

U.S. Department of Agriculture. 1975. Soil Taxonomy. U.S. Dep. Agr. Soil Conserv. Serv. Agr. Handbook No. 436.754 p.

Winward, A.H. 1970. Taxonomic and ecological relationships of the big sagebrush complex in Idaho. Ph.D. thesis, Univ. of Idaho, Moscow, Idaho. $80 \mathrm{p}$

Youtie, B.A., and A.H. Winward. 1977. Plants and plant communities of the John Day Fossil Beds National Monument. Unpublished report. Oregon State Univ., Corvallis, Ore. 81 p. 